\title{
Identifying local mechanisms for tumor-derived immunosuppression: an integrated phenotypic screening approach
}

David J Klinke

\author{
From Society for Immunotherapy of Cancer 29th Annual Meeting \\ National Harbor, MD, USA. 6-9 November 2014
}

Simply stated, clinical response to an immunotherapy is proportional to the product of three quantities: the total number of tumor-infiltrating lymphocytes (TILs), the proportion of tumor cells that can be recognized by these TILs, and the cytotoxic efficacy of TILs directed against tumor cells. Recent clinical responses to Ipilimumab illustrate that TILs recognize tumor cells and that modifying immune checkpoints can increase the total number of T lymphocytes. Yet until we identify which of the many putative or potentially undiscovered local biochemical mechanisms limit the cytotoxic efficacy of TILs, the subset of patients that respond to these immune checkpoint modulators will be limited, as is the current state for Ipilimumab. To address this problem, we have developed a phenotypic screening workflow to identify local mechanisms that malignant cells use to suppress anti-tumor immunity. Specifically we have focused on identifying tumor-derived cues that locally suppress lymphocyte response to Interleukin-12, a key link between innate and adaptive immunity. By integrating high content assays, proteomics, and in silico methods, we identified tumor-derived Wnt-inducible signaling protein-1 (WISP1) as a paracrine suppressor of T cell response to IL-12 in vitro [1,2]. In patients with invasive breast cancer, we found that WISP1 is up-regulated in essentially all tumor samples from patients with invasive breast cancer [3]. While a type 1 immune response was correlated with improved survival in these patients, we also found that the expression of WISP1 correlated with a shift in immune polarization from a type 1 to a type 2 response. This observation is consistent with WISP1 as a paracrine regulator of immune response to IL12. Overall, this example serves to illustrate how a quantitative systems

West Virginia University, Morgantown, WV, USA approach can be used to inform therapeutic strategies that enhance anti-tumor immunity and overcome local mechanisms for immunosuppression.

Published: 6 November 2014

\section{References}

1. Klinke DJ, Cheng N, Chambers E: Quantifying crosstalk among Interferon$\gamma$, Interleukin-12, and Tumor Necrosis Factor signaling pathways within a TH1 cell model. Sci Signal 2012, 5:ra32.

2. Kulkarni YM, Chambers E, McGray AJ, Ware JS, Bramson JL, Klinke DJ: A quantitative systems approach to identify paracrine mechanisms that locally suppress immune response to Interleukin-12 in the B16 melanoma model. Integr Biol (Camb) 2012, 4:925-36.

3. Klinke DJ: Induction of Wnt-inducible signaling protein-1 correlates with invasive breast cancer oncogenesis and reduced type 1 cell-mediated cytotoxic immunity: A retrospective study. PLoS Comput Biol 2014, 10: e1003409.

doi:10.1186/2051-1426-2-S3-P135

Cite this article as: Klinke: Identifying local mechanisms for tumorderived immunosuppression: an integrated phenotypic screening approach. Journal for ImmunoTherapy of Cancer 2014 2(Suppl 3):P135

Submit your next manuscript to BioMed Central and take full advantage of:

- Convenient online submission

- Thorough peer review

- No space constraints or color figure charges

- Immediate publication on acceptance

- Inclusion in PubMed, CAS, Scopus and Google Scholar

- Research which is freely available for redistribution 